\title{
Imagem Marota do Satélite CBERS 2B
}

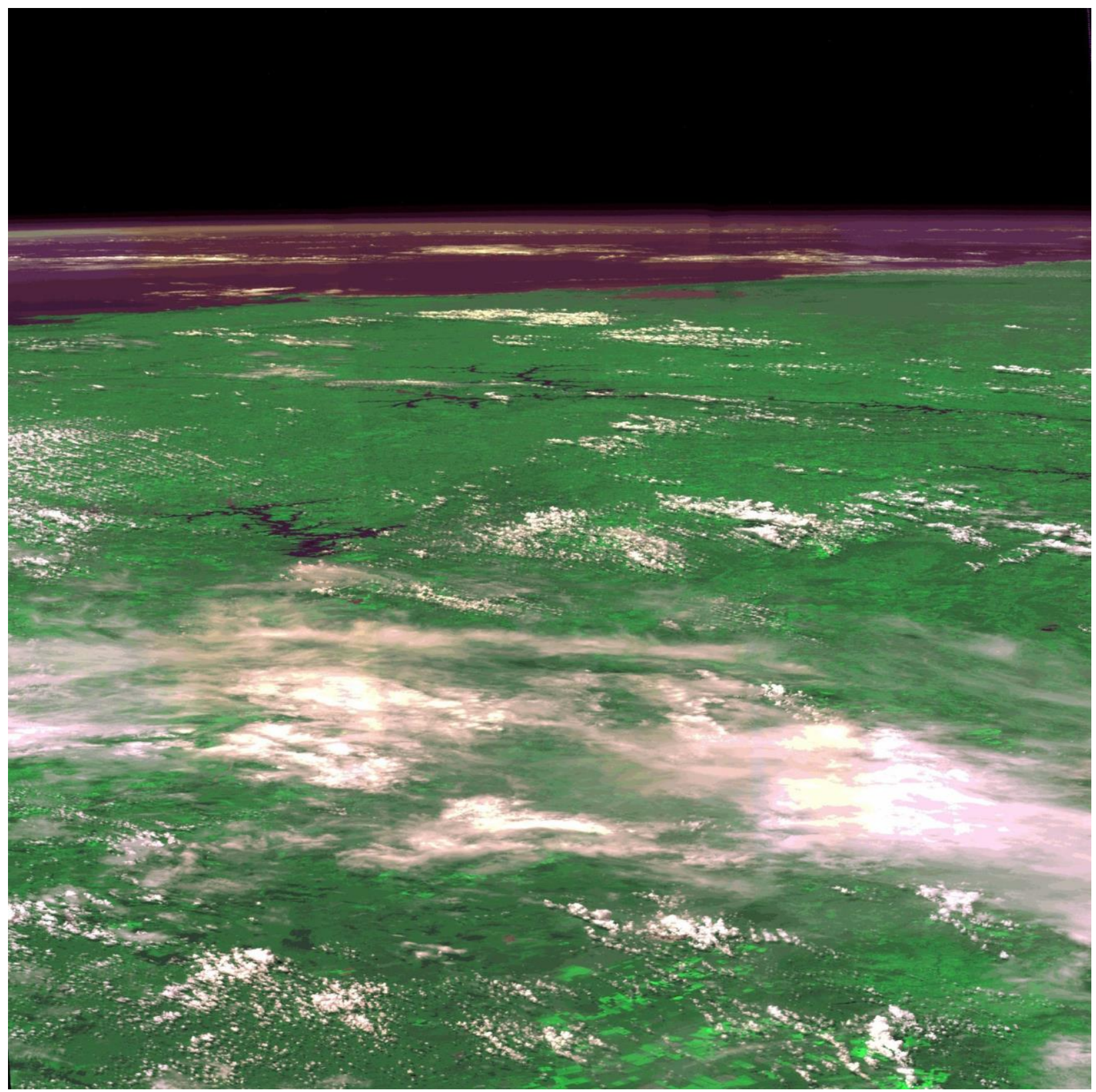

Perto do fim da vida o satélite de Sensoriamento Remoto Sino-Brasileiro CBERS-2B, pense uma câmara fotográfica espacial, começou a ter um comportamento estranho. Começou a dar cambalhotas e capturou essa imagem peculiar, acima. 
A câmara WFI é projetada para apontar ao Nadir do satélite, para baixo. Já essa, parece com fotografias panorâmicas de reconhecimentos aéreo, feitas em janela especial na lateral do avião, com a câmara apontando para o lado. Imagem única, inesperada e muito bonita, na minha opinião.

Em preto, na parte de cima da imagem, o espaço. As estrelas, e algum eventual planeta, estão lá, mas não aparecem ofuscados pela luz do Sol, muito mais potente, que ilumina o Planeta Terra. Em branco, nuvens. Água também aparece em cor escura. Está levemente arroxeada pela atmosfera sobre o Oceano Atlãntico. No continente, domina em cor verde a vegetação, mais clara nas áreas agrícolas, mais escura em florestas e reflorestamentos, onde há mais sombra. Ainda no continente, duas grandes manchas negras se destacam. À esquerda o lago do Reservatório de Três Marias, no Rio São Francisco, à direita o Reservatório de Furnas, no Rio Grande, ambos em Minas Gerais. Observando com cuidado é possível distinguir a Ilha de São Sebastião e uma grande mancha avermelhada próxima ao litoral, a Grande São Paulo. Na esquerda da imagem o canto Sul da Baía da Ilha Grande e a península onde fica Paraty, no Rio de Janeiro.

Voltando ao CBERS 2B. Como isso aconteceu? Era esperado?

Sim. o ambiente espacial é muito inóspito, lá não existe a proteção contra os raios cósmicos primários que a atmosfera da Terra nos dá. Esses raios, digo, partículas, íon pesados, destroem fisicamente os componentes eletrônicos dos satélites. Existem blindagens contra radiação e redundância de sistemas, mas aí entram as limitações de massa. Cada grama a mais em um satélite implica em alto custo energético, para escapar do poço de gravidade do planeta. É uma soluçao de compromisso, que limita a vida útil das espaçonaves em geral.

Com o desgaste sofrido pelos equipamentos a bordo do CBERS $2 \mathrm{~B}$ ao final da sua vida útil planejada, em Março de 2010, os giroscópios primários, Chineses, falharam. Foram acionados os giroscópios Russos, que também vieram a pifar. A orientação por estrelas, com um mapa do céu, ídem. Sensor de horizonte também. Várias manobras foram tentadas para controle do rolamento, inclusive com o uso dos propulsores a hidrazina. Na imagem apresentada, a atitude do satélite está estável, mas apontando para o lado. 
A última imagem que passou no controle de qualidade do INPE foi no dia anterior, a CB2BWFI16709220100310. Seu nome indica o satélite, sensor, órbita, ponto, ano, mês e dia.

Depois disso a coisa piorou, o CBERS ${ }_{2} \mathrm{~B}$ passou a adquirir imagens durante as mudanças de atitude, tendo como resultado imagens semelhantes ao efeito de rastro em fotografia. Borradas.

O CBERS 2B tinha cumprido bravamente sua missão. Estava morrendo.

Cerca de 2 meses depois, a comunicação com o satélite foi perdida. O satélite é oficialmente considerado inativo desde 12 de Maio de 2010.

Hoje em dia o CBERS 2B é lixo espacial. Se quiser saber onde ele está agora busque por "2007042A".

\section{Referências:}

1. Comunicação verbal, Zeca Bacelar \& Júlio D’Alge da Divisão de Processamento de Imagens do INPE.

2. Ajuda na interpretação visual para localizar a imagem de Marcos da Costa Pereira da Divisão deSensoriamento Remoto do INPE.

3. Mais informações sobre nossos satélites de Sensoriamento Remoto no site da Divisão de Geração deImagens do INPE em http://www.dgi.inpe.br/siteDgi/portugues/satelites.php < no portal links para todos os catálogos de imagens armazenadas e distribuídas gratuitamente pelo INPE para download em tempo quase real, média de 4 minutos>.

4. Mais detalhes sobre o $\quad$ Programa $\quad$ CBERS http://www.cbers.inpe.br/lancamentos/cberszb.php

5. More info about CBERS $2 \mathrm{~B}$ in English at http://space.skyrocket.de/doc sdat/cbers-1.htm 